\title{
Doživljajska pedagogika v Sloveniji skozi teorijo in prakso
}

\author{
Mitja Krajnčan in Damjan Habe \\ Univerza na Primorskem, Pedagoška fakulteta \\ Mladinski dom Jarše, Ljubljana \\ Univerza na Primorskem, Pedagoška fakulteta
}

\section{Uvod v teorijo doživljajske pedagogike}

Doživljajsko pedagogiko pojmujemo kot metodo vzgojno-izobraževalnega dela, kot učno metodo ali kot vzgojni ukrep. Njen imanentni cilj je vzgoja. Temelji na celostnem pristopu, ki ne izključuje nobene bistvene komponente človeškega bitja in se lahko $\mathrm{v}$ grobem naslovi s srcem, glavo in rokami. Torej ne favorizira kognitivne komponente, kar ne pomeni, da jo zanemarja, ampak $\mathrm{v}$ nasprotju $\mathrm{z}$ etabliranim šolstvom ne zanemarja čustvene, fizične in duhovne plati otrokovega učenja, ki lahko ponudijo marsikateremu otroku, ki ima težave $\mathrm{v}$ dokazovanju svojih sposobnosti, pomembno izhodišče za nadaljnji razvoj. Pravimo sicer, da je doživljajska pedagogika pedagogika mladostništva, saj na legitimni ravni omogoča preverjanje lastnih meja. Vendar ugotavljamo, da ima posebej močan ugoden vpliv na otroke in mladostnike z vedenjskimi, čustvenimi in učnimi težavami. Metodična ustreznost se mora zrcaliti skozi individualizirana merila, pri čemer na skupino in njen socializacijski pomen ni pozabljeno.

Doživljajskopedagoški mediji so usmerjeni v naravo in v soustvarjanje projektov $\mathrm{z}$ vsemi člani skupine od vsega začetka naprej. To posledično izzove soodgovornost za izpeljavo projekta in mlade postavi $\mathrm{v}$ drugačno vlogo, kot jim jo ponuja potrošništvo, kjer so v mnogočem najboljša ciljna skupina.

Pedagoški eros in etos sta pravšnji kategoriji pri definiranju osebe doživljajskega pedagoga, kjer je potrebno ozavestiti svoje delovanje in $\mathrm{v}$ pro- 
jekte pritegniti strokovnjake različnih področij, od mornarjev, alpinistov do gozdarjev ipd.

Pedagoški cilji so postavljeni na osebna področja mladih, na socialno, motorično in kognitivno področje.

Problematika transfera $\mathrm{v}$ domače okolje ima namen osvetliti ozaveščanje razpoloženja med počitnicami in prostim časom, neadekvatnost medijev, na kratkotrajne ponudbe, pomanjkljivo evalvacijo. Temu nasproti je potrebno postaviti jasne cilje, dolžino doživljajskopedagoškega procesa, dolgoročno in homogeno skupinsko strukturo, ustrezne medije in refleksivno obdelavo. Prav tako je potrebno ozavestiti meje in nevarnosti ter tako poskrbeti za varnost.

Doživljajska pedagogika je področje pedagoške znanosti oz. pedagoška disciplina, ki je postala $\mathrm{v}$ zadnjih desetletjih tudi znanstveno utemelje$\mathrm{na}^{\mathrm{I}}$ (Krajnčan, 2007). Je znanstvena sinteza praks, ki poudarja celostno pedagogiko, osebno - odnosno ${ }^{2}$ noto ter neposredno izkušnjo kot pomembne elemente pedagoškega delovanja, ki se med seboj pomembno povezujejo (Krajnčan, 2006). Doživljajska pedagogika je način vzgajanja otrok in mladostnikov oz. vzgoja za življenje (Krajnčan, 2007; AFET, 1992 v Krajnčan, 2007). Doživljajska pedagogika se pomembno vključuje v sistem socialnopedagoške pomoči, v vzgojno-izobraževalne namene, prevencije, terapije ter sega tudi na področje prostočasne pedagogike. Uporabna je kot metoda za doseganje različnih pedagoških ciljev (Krajnčan, 2007).

Doživljajsko pedagogiko lahko razumemo kot metodo usmerjeno $\mathrm{k}$ aktivnosti, delovanju, pri kateri preko skupine in doživetij v naravi ali pedagoško kontroliranih osamljenih prostorih v naravi pridobivamo življenjsko pomembne izkušnje in kompetence, ki služijo pedagoškim smotrom ter osebnostni rasti otrok in mladostnikov (prirejeno in dopolnjeno po Heckmair in Michl, v Krajnčan, 2007). Doživljajska pedagogika je torej metoda, ki želi oblikovati vzgojni proces skozi zgledne učne procese, $\mathrm{v}$ katerih izzovemo (fizično, psihično in socialno) mlade ljudi, da bi osebno-

1 Znanstvena utemeljenost doživljajske pedagogike omogoča ustrezno edukacijo doživljajskega pedagoga, torej njegovo vzgojno in izobraževalno delo, po drugi strani pa doživljajskopedagoška praksa bogati doživljajskopedagoško znanost (Krajnčan, 2007).

2 Doživljajska pedagogika zelo poudarja tudi odnosni vidik, odnosno energijo med pedagogom in udeleženci doživljajskega projekta. V luči tega je potrebno v doživljajskih projektih upoštevati tudi pedagoški eros, ki predstavlja duhovno ljubezen do otrok in mladostnikov ter njihovega vzgajanja (Krajnčan, 2006). 
stno rastli, ter prispevamo k njihovi odgovornosti za njihov življenjski svet (Krajnčan, 2007).

Doživljajska pedagogika je metoda, ki temelji na izkustvenem učenju, spoznavanju sebe in razvijanju skupinske dinamike. Predstavlja lahko eno izmed možnosti pomoči otrokom oz. mladostnikom pri lažjem vključevanju v družbo, v manjše ali večje socialne enote in pri razvijanju lastnih potencialov. Običajno se izvaja $v$ tesnem stiku $\mathrm{z}$ naravo, ključnega pomena pa je tudi gibanje, ki ima za zdrav razvoj mladostnika velik pomen (Farkaš, 2013). Doživljajska pedagogika si prizadeva zagotoviti možnosti in priložnosti za zdrav razvoj posameznika, ohraniti želi pristen stik z naravo ter spodbujati njeno ohranjanje ter stremi k družbi, ki bi imela več občutka za sočloveka, ne glede na socialno pripadnost, barvo kože, svetovni nazor, telesno višino, številko noge, versko prepričanje ali spolno usmerjenost (Krajnčan, 2007).

Freire (1970) je predlagal, da izobraževalna praksa združuje tako akcijo kot refleksijo kot del izobraževalnega procesa. Ali kot radi rečemo, najboljši nasvet je izkušnja.

\section{Načela doživljajske pedagogike}

$\mathrm{V}$ ta namen je potrebno osvetliti načela, ki dajejo orientacijo in strukturo, preko katere lahko rečemo, da se ne ukvarjamo s fragmenti ali metodičnimi paberki doživljajske pedagogike, ki na koncu koncev to niso, ampak dejansko z metodo, ki ima smiselni okvir in celoto.

Celostnost kot nasprotje prevladujočim pogojem in strukturam učenja in življenja je najpomembnejše načelo doživljajske pedagogike. Prikazati želi alternativo enostranskosti posredovanja znanja, ki je usmerjeno v racionalnost in intelekt, in razdrobljenosti življenja na posamezna področja. Pogosto predstavljeni kot merilo vsesplošne uspešnosti in z njo tekmovalnosti. Tako se lep delež mladih znajde v spirali nasilja razdeljevanja, na tiste, ki so in tiste, ki so odvečni.

Celostnost v doživljajski pedagogiki obsega več področij. Na individualnem področju se trudi za skupno udeležbo telesa, duše in duha pri vsakokratnem dogajanju. Poleg tega gre za odpravo ločevanja med teorijo in prakso, pri čemer naj se teoretično znanje ne presoja enostransko (Ziegenspeck, v Krajnčan, 2006, str. 21).

V doživljajski pedagogiki so čustveni, umetniški, spretnostni, socialni in kognitivni učni elementi drug drugemu enakovredni, pri čemer ima te- 
lesno področje pri učenju pomembno vlogo. Čim bolj se namreč »telesno« izrinja iz učnih in vzgojnih procesov, tem bolj gre ta učni in vzgojni proces mimo celostno zasnovanih človeških potencialov in sposobnosti (Priest in Gass, 1997).

Naravnanost k delovanju; kultura današnjega časa posebej v velikih mestih in gosto naseljenih območjih močno omejuje možnosti gibanja $\mathrm{v}$ naravnem svetu (Ziegenspeck, 1992). Na mesto lastnih, neposrednih izkušenj so nujno stopile izkušnje »iz druge roke«: potrošništvo in preplavljenost $\mathrm{z}$ dražljaji namesto lastnih aktivnosti. Čas tako preganjamo s pasivnim ukvarjanjem (mediji). Doživetja iz druge roke, kot jih posreduje televizija, npr. pasivno gledanje športa, ne morejo nadomestiti samopridobljenih, samoosvojenih in intenzivno doživetih izkušenj in zapuščajo »nenasičeno dramatično potrebo«. Doživljajska pedagogika se zato usmerja $\mathrm{k}$ nujnosti samoaktivnosti, ustvarja si okvirne pogoje, ki preprečujejo pasivno udeležbo. Udeležencem mora postati jasno, da bodo lahko spremenili svoje življenjske pogoje ali se kaj naučili le z lastno aktivnostjo, da si bodo na preprostem, nazornem, jasno začrtanem polju delovanja, »tukaj in zdaj«, razjasnili povezavo med naprezanjem in rezultatom. Telesno moč je mogoče smiselno uporabiti za vsakodnevna življenjska opravila.

Naravnanost $k$ delovanju omogoča zbiranje uspehov tudi tistim mladostnikom, ki zgolj zaradi manjših intelektualnih zmožnosti ali težav pri komunikaciji le redko dobijo priznanje.

Naravnanost k skupini; doživljajska pedagogika je po načinu svojih postopkov neposredno vezana na obliko skupinskega dela. Skupinske procese vzpodbujajo okvirni pogoji projekta oz. dejavnosti. Doživljajska skupina se pogosto opira sama nase in ima komaj kaj stikov z vsakdanjim okoljem. Tako je aranžiran nekakšen »vsakdan«, v katerem so odsotni najrazličnejši odkloni sicer znanega življenjskega okolja. Zaradi zaprtega socialnega prostora se pokaže, da je v konfliktnih situacijah možnost umika ali izognitve dejanskemu toku skupinske dinamike skorajda nična. Aktivnosti so oblikovane tako, da so mladostniki brezpogojno odvisni drug od drugega. Nujno je sodelovanje, ker se drugače ekipa ne premika v pravo smer; nujna je komunikacija, saj je treba razdeljevati skupinske naloge in se pogovarjati o dnevnih načrtih; nujna je odgovornost, saj je lahko ogrožena varnost vseh, če se izgubi ali poškoduje samo kak posamezen del opreme; in nujno je zaupanje, saj ima tisti, ki sredi brzice ali na steni drži varovalno vrv, včasih v rokah življenja drugih (Ziegenspeck, 1992; Krajnčan, 2006). 
Soodločanje in sooblikovanje; s pojmom "soodločanje« želimo usmeriti pozornost tudi na modalitete odnosov med mladimi in odraslimi (vzgojitelji, učitelji).

Pozitivno je, če mladim še v fazi priprav posredujemo občutek, da gre za »njihovo stvar«, in jih motiviramo k aktivnejšemu sodelovanju, k ustvarjanju pozitivnega vzdušja.

$\mathrm{V}$ normiranem in urejenem okolju, ki ga zaznamujejo nepregledne poti odločitev, na katere ni mogoče vplivati, si mladi naberejo komaj kakšno izkušnjo, da je prek nje njihovo sodelovanje kakorkoli mogoče vrednotiti (Ziegenspeck, 1992; Krajnčan, 2006).

Voditelji doživljajske pedagogike vedo, da služi pravilno načrtovanje, še preden stopijo s svojo skupino $\mathrm{v}$ zunanje okolje, kot glavni element varnega in uspešnega vodenja doživljajskopedagoškega projekta. Enako velja za načrtovanje okolju prijaznega izleta. Razumljivo je, da mnoge dimenzije, ki se skozi projekt pokažejo kot vprašljive, izhajajo iz pomanjkljivo pripravljenih priprav, kjer je pomembna dimenzija sooblikovanje, saj občutek, da gre za ^njihovo stvar, pomeni občutek odgovornosti. To pomeni, da so vključeni v soodločanje, saj le tako lahko pričakujemo zaželene rezultate.

Nove možnosti odnosov; doživljajska skupina nudi s svojim aranžmajem možnost za spremembo nastalih razmerij in vzorcev vlog ter za vzpostavitev novih razmerij tako med mladimi kot tudi med njimi in pedagogi. Zunanji pogoji doživljajskopedagoškega procesa pa vsem udeležencem postavljajo vedno nove zahteve v zvezi z njihovo pripravljenostjo in sposobnostmi. Nujno je opustiti prejšnje odnosne vzorce, npr. pasivnost ali umik, s čimer je mogoče zadovoljiti potrebe (Ziegenspeck, 1992; Krajnčan, 2006).

Nove in nepričakovane naloge ter situacije lahko odnose spremenijo dosti bolj, kot je to mogoče v urejeni instituciji.

Naravnanost na potrebe mladih; med puberteto in adolescenco je mladostnik v fazi radikalnih fizičnih in psihičnih sprememb. Biološki vidik vsebuje nagle in občutne telesne spremembe, ki jih povzroča povečano izločanje hormonov. Hitra rast prinaša večjo potrebo po gibanju in aktivnostih. Preizkusi poguma in razna ravsanja se prirejajo za testiranje moči in spretnosti. Doživljajskopedagoško skupinsko delo daje zakonite možnosti za zadovoljitev teh potreb. Ko se približujejo svojim mejam, lahko mladi spoznajo svoje telo in se dokopljejo do boljšega presojanja samega sebe (Ziegenspeck, 1992; Krajnčan, 2006).

V tej življenjski fazi je za mladostnika osrednjega pomena vprašanje o njegovi identiteti. Sprašuje se o svoji vrednosti, o svojih slabostih in krepos- 
tih. V tem obdobju se zgradijo in izoblikujejo lastni življenjski cilji in vrednostni sistemi (Ziegenspeck, 1992; Fischer, 1999).

Sociološko gledano predstavlja mladostništvo prehodni čas med otroštvom in odraslostjo, ki je povezan $\mathrm{z}$ ekstremno negotovostjo statusa in vloge. Te negotovosti skuša mladostnik premagati s samostojnimi dosežki. Raznovrstne aktivnosti, veselje do avantur, radovednost, eksperimenti na telesnem in socialnih področjih so nujne potrebe te življenjske faze, izraz iskanja samega sebe in izraz iskanja osebne identitete. Pristop, usmerjen $\mathrm{v}$ doživljaje in dejavnosti, zelo ustreza potrebam mladostnikov. Pregleden in strukturiran okvir nudi mnogotere možnosti za izkušnjo samega sebe in izgradnjo socialnega načina vedênja ter ureditev vrednostnega sistema (Ziegenspeck, 1992; Krajnčan, 2006).

Naravnanost k naravi; marsikje je svet mladostnikov sestavljen le še iz betona in asfalta. Mnogih naravnih procesov ne doživljajo več neposredno, temveč kvečjemu prek medijev, zato se komaj še lahko izoblikuje zdrav odnos do narave. Doživljajska pedagogika se orientira na zapuščanje stanovanjskih področij in s preživljanjem $\mathrm{v}$ naravi posreduje izkušnjo kontrasta. "Neposredne« čutne izkušnje omogočata skupina in narava.

Narava s svojo avtoriteto prispeva k vzgojni usmerjenosti projekta.

Ven iz vsakdana; doživljajska pedagogika nudi v nasprotju s potrošniško enoličnim vsakdanom mnogo kontrastov, ki spodbujajo razmišljanje in posredujejo izkušnje: ven iz poplave dražljajev v življenje brez medijev, prometa in vrveža; samopreskrba namesto preobilna oskrba; prevzemanje različnih in nevsakdanjih vlog; relativno preprost način življenja namesto vsakdanje tehnike $\mathrm{v}$ prometu, kuhinji, med prostim časom ipd.; improvizacija in kreativnost namesto potrošništva; narava namesto betona; veter in vreme namesto klimatskih naprav; naravni življenjski ritem namesto prilagajanja šolskemu zvoncu, hišnemu redu ali čakanju, kdaj nastopi vzgojitelj svoj turnus ipd. (Ziegenspeck, 1992; Fischer in Mroczek, 2004). Dati krila tam, kjer so vzgojne metode podlegle. Ponuditi tisto, kar ni prisilno, čeprav je le-to dojeto kot nekaj vsakdanjega, normalnega. Treba se je boriti in skušati zajeziti avtoriteto, imenovano potrošništvo, četudi z begom v neznano okolje. Preglednost, življenje brez ustaljenih impulzov, dražljajev ponuja nove dimenzije socialnega učenja in dela na sebi (Ziegenspeck, 1992; Krajnčan, 2006).

\section{Doživljajskopedagoški cilji}

Pri metodičnem planiranju je treba odgovoriti na nekaj vprašanj. Za uspeh projekta je zelo pomembno, da pobudniki pred začetkom jasno opredelijo 
cilje, ki tedaj postanejo sredstvo, od katerega sta odvisni vsebina in podoba (Krajnčan, 2007).

Gre namreč za vprašanja, ali bodo bolj poudarili izobraževanje ročnih in motoričnih spretnosti in znanj ali pa bodo spremljevalci dajali več nasvetov, pobud, posredovali več teorije in opredelili $\mathrm{v}$ učnih vsebinah in vajah večjo strukturiranost. Če so v ospredju bolj osebnostni in socialni cilji, bodo vodili več informativnih individualnih pogovorov in več pozornosti posvetili skupinskemu procesu in vzpostavljanju odnosov. Čeprav so lahko učni cilji doživljajske pedagogike enaki tistim, ki prihajajo iz institucij, se njen učni proces občutno razlikuje. Posredovanje znanj in sposobnosti ne poteka v verbalnem seminarskem stilu, se pravi »iz glave v roke«, temveč prek dejavnega soočanja $\mathrm{z}$ nalogami in problemi »iz rok v glavo«. To velja tako za kognitivne kot za socialne učne cilje. Katalog učnih ciljev je mogoče razdeliti na več področij, pri čemer je lahko seznam v nadaljevanju le eksemplaričen in nikakor popoln (Breß, 1985). Poleg tega so posamezni cilji popolnoma odvisni od aranžmaja, skupine udeležencev, trajanja, institucije ipd. (Breß, 1985; Ziegenspeck, 1992; Fischer, 1994; Krajnčan, 2006).

\section{Cilji na osebnem področju}

Cilji na osebnem področju merijo na krepitev samozaupanja in pripravljenosti na sodelovanje, doživetja uspeha, spodbujanje izkustva in odkrivanja samega sebe, podpiranje izgradnje identitete, učenje, kako potrebe odložiti na kasnejše priložnosti, gradnjo vzdržljivosti; spodbujanje kreativnosti in zmožnosti improviziranja (socialna in spretnostna fantazija), pridobitev sposobnosti povezovanja in zaupanja drugih oseb, spodbujanje komunikacijskih spretnosti (kako posredovati veselje in bojazen, izraziti potrebe, sodelovati pri skupinskih odločitvah), prevzemanje odgovornosti zase in za druge, spoznavanje in motivacijo za drugačno preživljanje prostega časa, ponovno vzpostavljanje pozitivne naravnanosti do učenja, spodbujanje samoiniciative (razvoj občutka za kompetentno delovanje), posredovanje vtisov in lepih doživetij, ki ostanejo (Breß, 1985; Ziegenspeck, 1992; Fischer, 1994; Krajnčan, 2006).

\section{Cilji na socialnem področju}

Razvijanje občutka za skupino in občutka pripadnosti, solidarnosti, pripravljenost pomagati, sodelovanje, razvijanje pravil in njihovo upoštevanje, odkrivanje konfliktov in razvoj kompromisov, razumevanje in tolerantnost 
do šibkejših, drugačnih, sprejemanje nalog in odgovornosti za skupino, razvijanje senzibilnosti za občutke in probleme drugih.

Izkušnja intenzivne skupine se ob individualizaciji življenjskih svetov mladih pokaže za mlade kot pomembna kategorija. Socialno področje izkusijo v intenzivni, pregledni, majhni skupini, kjer je mogoče usmerjati ustrezno pedagoško delovanje. Smer je pridobivanje socialnih kompetenc, kar vodi do boljše in sprejemajoče drže pri vključevanju v okolje. Institucionalna vzgoja je na tem mestu specifična kategorija vzgoje, saj želi prenašati vrednote prek posredovanja kakršnegakoli znanja. Signifikantno je to poudarjeno $\mathrm{v}$ totalnih vzgojnih institucijah, kjer je zmeda glede kategorij posredovanja znanja in vrednot še nekoliko večja, vendar javni kritiki in strokovnim vplivom manj dostopna (Breß, 1985; Ziegenspeck, 1992; Fischer, 1994; Krajnčan, 2006).

\section{Cilji na motoričnem oz. spretnostnem področju}

Posredovanje izkušenj znanja, razvijanje grobe in fine motorike $\mathrm{z}$ raznimi športnimi aktivnostmi in ročnimi dejavnostmi, učenje tehnik različnih športov (predvsem v naravi, kot so jadranje, kajakaštvo, smučanje, plezanje), posredovanje telesnih izkušenj, razvijanje sposobnosti za smiselno preživljanje prostega časa, motivacija za športne in ročne dejavnosti, ki naj traja tudi po končanem doživljajskopedagoškem procesu - to so nekateri cilji, vendar se ob njih zavedamo, da imajo vsekakor premalo motorične vzgoje.

Področje pomeni tudi intenziven stik z lastnim telesom, saj teh izkušenj mladim prej primanjkuje, kot pa da bi jih imeli preveč. S telesnim se mladi soočajo bolj odtujeno kot kadarkoli prej, saj običajen otrok nima dovolj izkušenj lastnih naporov, fizičnih dejavnosti, aktivnosti, hkrati pa je bombardiran in prenasičen $\mathrm{z}$ formami in simboli, ki ga oddaljujejo od dejanske izkušnje sebe (Breß, 1985; Ziegenspeck, 1992; Fischer, 1994; Kiphard, 2001; Krajnčan, 2006).

\section{Cilji na kognitivnem področju}

Pred ali med projektom se vedno posredujejo tudi vsebine nekih znanj, ki nastanejo iz vprašanja ali ob pomoči situacije. Prav neposredna zveza vsebin s praktično uporabo se je pokazala kot najugodnejši učno-psihološki faktor. Navedimo le nekaj primerov znanja, ki jih je mogoče pridobiti: gospodinjsko znanje (nakup, računanje in priprava za oskrbovanje), ročno znanje in spretnosti, vremenoslovje, prometno oz. navtično znanje, orien- 
tiranje z zemljevidom in kompasom, biološke, geografske, geološke vsebine ipd. (Breß, 1985; Ziegenspeck, 1992; Fischer, 1994; Krajnčan, 2006).

\section{Tveganje na doživljajskopedagoških dejavnostih}

$S$ poznavanjem razlike med nevarnostjo in hazardi ter z zmožnostjo, da jih prepoznamo v naravnem okolju, lahko zmanjšamo možnost, da je skupina izpostavljena nezaželenim tveganjem. Kot primer ilustracije si zamislite planinarjenje, ki vključuje ledenik na potovanju na vrh. Da bi preprečili kakršnekoli nezaželene dogodke, moramo ustrezno analizirati možne nevarnosti. Uporabimo naslednji postopek desetih korakov analize nevarnosti kot način, s katerim lahko zmanjšamo verjetnost, da se bo nesreča zgodila, in če se že zgodi, da zmanjšamo njene posledice na sprejemljivo in obnovljivo raven (Priest in Baillie, 1987).

Priest in Gass (1997, str. 90) sta v ta namen izpostavila 1o korakov, ki jih je treba upoštevati v doživljajskopedagoških projektih.

1. Planirajmo vnaprej. Priznajmo si, da se nesreča lahko zgodi tudi nam. Če si mislimo, da se to ne more zgoditi nam, se norčujemo iz samega sebe. Verjetnost je, da se bo enkrat v naši karieri vodje doživljajskopedagoških projektov nesreča zgodila kljub našemu največjemu trudu. Vprašanje ni, ali se bo to zgodilo, temveč, $k d a j$ ! Pripravljeni moramo biti, da se spoprimemo skoraj $\mathrm{z}$ vsem, kar se lahko zgodi, in vzdržujemo "ponižen položaj« kot vodja. Prednačrtovanje je bistvenega pomena. Vedeti moramo, kaj bomo storili ob vsaki morebitni nesreči, preden se zgodi.

2. Iščimo nevarne situacije in pogoje. Vzpostavimo neprekinjeno iskanje, da bi identificirali nevarnosti. Moramo ostati pozorni na nevarnosti, v katerikoli situaciji. Nujno si je predstavljati, kaj se lahko zgodi, v kateremkoli trenutku. To pogosto dosežemo s stražarsko budnostjo za vse sumljive okoliščine in z nenehno pripravljenostjo, da se vprašamo »Kaj če?«. Kadar je prisotnih več nevarnosti, vzamemo to kot opozorilo, da bi bili dodatno alarmirani (budni) in previdni. Vedno izvedemo ustrezne reakcije za ravnanje v nevarnosti.

3. Označimo si potencialne nevarnosti. Ko enkrat identificiramo nevarnosti, usmerimo pozornost uporabnikov in sodelavcev nanje. Na primer, usmerjanje uporabnikove zavesti na nevarnosti iz 
okolja lahko zmanjša verjetnost nesreče, ker prepoznavajo potenciale za nesrečo, kar pogosto zadostuje, da se vedênje spremeni.

4. Kadar je ustrezno, umaknemo elemente, ki so lahko potencialno nevarni. Če usmerjanje pozornosti na nevarnost ne deluje, umaknemo nevarnost, dokler umikanje ne povečuje tveganja, da se zgodi ta ali druga nevarnost.

5. Izogibajmo se nevarnim situacijam. Če ne moremo odstraniti nevarnosti, se ji skušajmo izogniti. To lahko pomeni spremembo poteka doživljajskopedagoškega projekta. Spremenimo dejavnost popolnoma $\mathrm{v}$ drugačno smer, uberimo nov načrt, skličimo postanek, prekličimo program in dejavnost. Za namen projekta je občasno nujno, da se soočimo $\mathrm{z}$ nevarnostmi.

6. Identificirajmo in klasificirajmo nevarne situacije. Če nevarnosti ne moremo odstraniti ali se jim izogniti, je verjetno, da se bomo morali boriti z njimi, zato jih bomo morali klasificirati kot izvor izgube ali kot tveganje (pogoji, ki vplivajo na verjetnost izgube). Ta klasifikacija bi morala omogočiti, da bi se srečali z nevarnostmi, ko so tveganja minimalna, s tem bi reducirali tveganje nesreče.

7. Ocenimo tveganje in ponovno klasificirajmo nevarnost. Če se ne moremo izogniti nevarnosti, ocenimo tveganje potencialne nesreče. Nato bi morali ponovno klasificirati nevarnosti kot nevarnosti iz okolja, ki temeljijo na okoliščinah, ali kot človeške nevarnosti, ki temeljijo na skupini. Ta ponovna klasifikacija nam omogoči, da bi prepoznali, ali potencial za preseganje teh dveh sil in tveganje za nesrečo obstaja.

8. Ocenimo potencialne izgube. Če se kombinacija človeške nevarnosti in nevarnosti iz okolja pojavi, potem ocenimo verjetnost izgube. Odgovorimo si na dve vprašanji: »Koliko preseganja je pričakovanega?«, »Koliko je mogoče, da bo ta kombinacija vodila do nesreče? « Spomnimo se, da bolj številne in močnejše nevarnosti vodijo do večje verjetnosti za nesrečo. Zato bi morali identificirati ter oceniti število in moč nevarnosti v človeški kategoriji in kategoriji okolja.

9. Zmanjšajmo izgube. Če se pojavi tveganje za nesrečo kot verjetnost, toda še vedno ne kot absolutna verjetnost, izberimo potek dejanj, za katera je izid nesreče sprejemljivejši. 
10. Opravimo ustrezne prilagoditve. Če se pojavi izguba v nesreči (npr. poškodba), naredimo ponovno načrtovanje, primerne prilagoditve (npr. urnik). Odločimo se, kaj bodo naši protiukrepi, preden se nesreča zgodi. Potem ko bo to storjeno, nadaljujemo s primerno previdnostjo, $\mathrm{z}$ iskanjem novih nevarnosti, ki lahko narasejo in se združijo z že obstoječimi.

Kljub temeljiti analizi nevarnosti in pozornosti za dejavnike, ki ovirajo presojo, se nesreče lahko zgodijo! Ob taki nesreči se lahko zaporedje protiukrepov pokaže kot uporabno, ko si prizadevamo zmanjšati vpliv nesreče. Varnostne protiukrepe lahko razdelimo v tri kategorije, ki temeljijo na pravočasnosti njihove uporabe: proaktivne ali primarne, aktivne ali sekundarne ter reaktivne ali terciarne (Priest in Gass, 1997, str. 93).

Proaktivni ali primarni varnostni postopki se nanašajo na izvajanje vseh treningov pred programom, da bi se izognili nesreči ali da bi vsaj pripravili ustrezno odzivanje na nesrečo. Preventivni ali proaktivni ukrepi vključujejo pregled opreme, natančno preučitev varnosti, treniranje sposobnosti ali osebja, dovršenost legalnega administrativnega dela, pregled potencialnih nevarnosti iz narave in človeških nevarnosti ter podroben pregled uporabnikovega zdravstvenega stanja.

Aktivni ali sekundarni postopki se nanašajo na vse dejavnosti, izvedene med programom, ponavadi kot rezultat nesreče. Odzivni ali aktivni ukrepi vključujejo prvo pomoč, iskanje in reševanje, evakuacijo, beleženje podatkov o poškodbi na kraju dogodka ter odzivne postopke.

Reaktivni ali terciarni se nanašajo na vse dejavnosti, ki se pojavijo po nesreči. Ukrepi, ki sledijo dogodku, ali reaktivni ukrepi vključujejo obveščanje sorodnikov in sponzorske organizacije, zaključno dokumentiranje nesreče, vzpostavljanje stika z legalnimi svetovalci ali predstavniki zavarovanja ter načrtovane obiske pri poškodovanem uporabniku na domu ali v bolnišnici (Ziegenspeck, 1993; Krajnčan, 2006).

\section{Različna poimenovanja in pristopi}

Obstajajo specifični pristopi in poimenovanja nekaterih podobnih dejavnosti in pristopov, tako $\mathrm{v}$ ponudbi prostočasnih aktivnosti kot pomoči specifičnim skupinam uporabnikov, od otrok in mladostnikov s posebnimi potrebami do odraslih skupin, pri delu s starostniki in kot didaktično metodično dopolnilo v osnovnih in srednjih šolah, ponekod tudi v vrtcih. 
Termin »doživljajska pedagogika« danes največkrat razumemo kot naravno ${ }^{3}$-športno usmerjene dejavnosti: na vodi, kopnem in $\mathrm{v}$ zraku. Omenjeno razumevanje je po mnenju nekaterih enostransko in ozko, saj se usmerja (samo) v zunanje pedagoške dejavnosti - »outdoor«, ter ne poudarja notranjih, zaprtih ${ }^{4}$ pedagoških dejavnosti, prostorov - »indoor « (Ziegenspeck, 2005; Fischer, 2004; Michl, 2000, v Krajnčan, 2007).

Poleg doživljajske pedagogike se v literaturi pojavljata še izraza »avanturistične« in »akcijske pedagogike«, ki sta sopomenki terminu »doživljajska pedagogika« (Krajnčan, 2007).

Termin izhaja $\mathrm{v}$ germanskem prostoru iz Hahnovega poimenovanja doživljajska terapija (Erlebnistherapie) v drugi polovici dvajsetega stoletja. $\mathrm{V}$ nadaljevanju se je preimenoval $\mathrm{v}$ doživljajsko pedagogiko (Erlebnispädagogik). Sprva je bil center na Univerzi v Lüneburgu, kjer je bil tudi istoimenski inštitut (Institut für Erlebnispädagogik) z nosilcem prof. dr. Jörgom Ziegenspeckom in prof. dr. Torstenom Fischerjem, kasneje se je prenesla na univerzo v Augsburg z nosilcem prof. dr. Wernerjem Michlom in prof. dr. Michaelom Jagenlaufom. V zadnjem času se pojavlja na mnogih univerzah v nemško govorečem prostoru (Nemčija, Avstrija, Švica).

$\mathrm{V}$ anglosaškem prostoru se metoda imenuje izkustveno učenje ali izkustvena pedagogika (experiential learning ali experiential pedagogy), pojavlja se tudi termin »Outdoor adventure education«, ki bi bil še najbliže terminu doživljajska pedagogika. Umeščena je na trgu ponudb mladim $\mathrm{v}$ počitniškem času (največkrat v obliki kampov), kakor tudi kot metoda dela tako v šolskem kot univerzitetnem učenju (Off-Campus learning).

$\mathrm{V}$ skandinavskih državah je šola $\mathrm{v}$ naravi pomemben sestavni del kulture. Usmerjeni so v učenje (pogosto skozi projektno delo) zgodovine, kulture, obrti, ekofilozofije ipd. na prostem, v praktične spretnosti v realnem okolju na prostem, učijo se nordijskih smučarskih tradicij, doživljajo življenje na prostem $v$ različnih okoljih obale, gozdov in jezer ipd. Norvežani imenujejo metodo kar »friluftsliv«, kar pomeni v prevodu življenje na prostem ali rekreacija na prostem.

Na Finskem je del izobraževalne filozofije povezan $\mathrm{z}$ naravo, učijo se $\mathrm{v}$ njej o njej, ustvarjajo empatično razmerje $\mathrm{z}$ naravo, zdravje ipd. Je del ku-

3 »Elementi doživljajske pedagogike so povezani z naravo, vzgojo in izobraževanjem v preglednih in nadzorovanih pogojih, ki jih izvajalci usmerjajo v povezavi z vzgojno-izobraževalnimi cilji.« (Krajnčan, 2007, str. 9). srednjo šolo ter ostale zavode in institucije na področju vzgoje in izobraževanja ter tudi širše (področje socialnega varstva, podjetja itd.). 
rikuluma v vrtcih, šolah in univerzah. Znanje učencev se lahko vzpostavi s konkretnimi izkušnjami, interesi, čustvi in vrednotami skozi izobraževanje na prostem. Aktivirajo se različna čutila, okrepijo se vezi med afektivnim in kognitivnim področjem, kjer eno vpliva na drugo in zagotavlja most za višje sfere učenja. Pomembne so izkušnje iz prve roke in interaktivno učenje pri oblikovanju osebnih mnenj, odnosov in vrednot. Prednosti vključujejo tudi izboljšane medosebne in intrapersonalne interakcije; višja je okoljska ozaveščenost in etika skrbnega ravnanja; povečano je fizično, duševno in socialno zdravje in sposobnost učenja in koncentracije (Jeronen, Jeronen in Raustia, 2009; Marttila, 2017).

Kot je $\mathrm{v}$ tradiciji izkustvene in doživljajske pedagogike po Matti Telemäkiju, "gre za podobne pristope na Norveškem pri konceptu »friluftsliv«, na Švedskem pri »utomhuspedagogik«, v Nemčiji imamo Kurt Hahnovo filozofijo in »Erlebnispädagogik« ter v angleško govorečem svetu »adventure education «. V Sloveniji uporabljamo prevod iz nemškega jezika, in sicer doživljajska pedagogika.

V vzhodni Evropi in Balkanu se je doživljajska pedagogika nekje bolj, drugje manj začela razvijati ob koncu prejšnjega stoletja in do danes, podobno kot pri nas. Zametki novih ureditev so ponekod metodo uporabili izključno v pridobitvene namene, sčasoma so videli uporabno vrednost tudi $\mathrm{v}$ šolskem in socialnem sistemu.

\section{Razvoj doživljajske pedagogike v Sloveniji}

Kako je pravzaprav prišlo do doživljajske pedagogike v Sloveniji? Takratna asistentka na Pedagoški fakulteti v Ljubljani, takrat mag. Alenka Kobolt, je leta 1991 na predavanje povabila dr. Erich Kiehna, in sicer v okviru FICE Slovenija. Le-ta je med drugim znotraj svojih predavanj predstavil tudi možnosti, ki jih ponuja doživljajska pedagogika. Eden od avtorjev, Krajnčan, je stopil z njim v kontakt, cenjeni, žal pokojni, dr. Kiehn mu je poslal veliko literature za to področje in $\mathrm{v}$ naslednjem letu 1992, ko je pričel $\mathrm{z}$ delom kot vzgojitelj v Vzgojnem zavodu Logatec, je izpeljal prvi projekt doživljajske pedagogike »Logatčani na kolesih».

Od takrat smo izpeljali 319 projektov. Med njimi naštevamo pomembnejše, nad katerimi imamo neke vrste avtorizacijo. $\mathrm{V}$ vseh projektih smo imeli 4.145 otrok in mladostnikov iz cele Slovenije, tudi Nemčije, Hrvaške, Madžarske in Srbije. Med njimi naštevamo tiste, ki so se pojavljali pogosteje ali so bili po svojem učinku posebej izpostavljeni: 
- Indijanski tabori (Obujmo indijanske mokasine),

- Življenje na samotnem otoku (Pločica),

- Premagajmo Slovenijo z lastnimi močmi (s kolesi vzdolž Slovenije),

- $\quad$ Ljubljanica reka sedmih imen (peš in s kanuji po vseh 7 rekah),

- Življenje v starem mlinu,

- Jadranje na braceri,

- $\quad$ Živeti - ne lebdeti (projekt za otroke, nameščene v izvendružinsko vzgojo, ki nimajo med vikendi in počitnicami možnosti odhodov domov, trajajoč skozi celo leto)

- $\quad$ in še mnogi drugi.

V letu 1994 smo ustanovili Društvo za doživljajsko pedagogiko Slovenije, ki nam je predstavljalo pravno osnovo za pridobivanje sredstev, organiziranje seminarjev, konferenc, kongresov. V tem času smo izdali 15 številk revije Doživljajska pedagogika, izpeljali 3 mednarodne kongrese, letno vsaj en izobraževalni seminar in, kot rečeno, 319 projektov, skupaj 2.233 dni.

Prav tako smo leta 2000 dobili Evropsko nagrado Outward Bound za najboljši doživljajskopedagoški projekt, kar je posebej cenjeno priznanje in potrditev, da izvajamo kvalitetno strokovno in znanstveno dejavnost.

$\mathrm{V}$ takšnih in podobnih metodah ali pristopih do otrok ali mladostnikov, ne glede na njihovo pridnost, marljivost, nadarjenost, posebne potrebe, socialni izvor ipd. pride lahko do kolizije med togo in pusto znanostjo in praktično uspešnim delom. Ziegenspeck (2000), Fischer (2004), Michl (2000) in Krajnčan (2007) soglasno ugotavljajo, da je želena znanstvena eksaktnost na tako psihofizično zahtevnih dejavnostih omajana, da vemo, da projekti prinašajo pozitivne učinke na udeležence. Relevantna so vsekakor mnenja otrok in mladostnikov, ki s svojimi obrazi in energijo sevajo zadovoljstvo, kar v etabliranih šolskih in socialnih pristopih največkrat izostane.

V Sloveniji je razpoznavna na področju vzgojnih zavodov, stanovanjskih skupin, delu $\mathrm{z}$ vedenjsko in čustveno težavnimi otroki, tudi v osnovnih šolah, vrtcih, specialno pedagoških ustanovah in socialnem delu.

Doživljajska pedagogika je neposredno povezana $z$ reformno pedagogiko, z idejami, kako prezračiti šolske okvire, načine pomoči mladim ter kako jih s precej "zavožene« poti pripeljati ponovno bližje potrebam mladih, bližje logiki dejanskega življenja in uporabnega učenja. Lahko bi rekli, da je povezana z pedagoško filozofijo, saj se ukvarja s smislom izobraže- 
vanja, $\mathrm{s}$ kvaliteto odnosa, $\mathrm{z}$ možnostmi in priložnostmi v učenju, ki ostajajo neizkoriščene kljub vedenju.

Zdi se, kot da nočemo imeti boljše šole. Kot da je Althusser šolo za vekomaj ponudil politiki, ki ima samo en interes in to je vladati. Lažje vladajo, če je kritična misel odsotna, če je negativna selekcija pri izbiri učiteljskih poklicev, če je rezultat zašolan otrok, mladostnik, mlad odrasli, ki je brez kompetenc uvida v dejansko stanje, ki je oropan širokega, zvedavega, radovednega otroštva, uporabnih znanj, kritičnosti. Svojo odličnost izkazujejo z znanji potrebnimi za nacionalna preverjanja znanj, maturo, diplomo ipd., ki pa v realnem življenju odsevajo posameznika, ki se ve učiti, naučiti, ne glede na to, ali ga to zanima, ne glede na to, ali je to uporabno. Največkrat že ob objavi rezultatov omenjena znanja izgubijo na veljavi in teži.

Če $\mathrm{v}$ to godljo vštejemo še dejstvo, da šola samo potrjuje socialno stratifikacijo, to pomeni, da obstaja za nekatere šola kot prekletstvo, nekaj, kamor zelo hitro hodijo s težavo, nemotiviranostjo, nesrečo. Kakorkoli že, ni vse črno-belo. Vsekakor pa bi si šola lahko pričarala veliko več barv, pestrosti, svobode in avtonomije, ne pa da se udinja samooklicani politični eliti, ki je brez dneva prakse ali realne prakse in nikoli ni bila del šolskega vsakdana, razen kot učenci, mnogi že toliko let nazaj, da se še komaj kaj spomnijo. Pogosto tudi nimajo izobrazbe s področja, a ga kljub temu najbolj obvladajo in so nedotakljivi. Šolstvo je subtilno telo, v katerega bi bilo potrebno vlagati veliko, veliko več, saj pomeni razvoj družbe, pomeni odnos družbe do prihodnosti, pomeni osnovo za samospoštovanje in za spoštovanje lastne domovine, na katero bi lahko bili najbolj ponosni, pa žal nismo.

Zato je potrebno zavzeti ne samo kritično misel, ampak zahtevo po spremembi, zahtevo po tem, da bodo otroci dobili takšna znanja, takšne odnose in takšne možnosti, da bo šolski prostor res učenje za življenje in prostor, kamor bodo otroci želeli vstopati. Vse parole okrog šol so videti le kot politične floskule. Za zaključek tega razmišljanja si bom izposodil rek Alexandra Dumasa ml., ki se sprašuje, kako to, da imamo toliko inteligentnih otrok in toliko neumnih odraslih.

\section{Sklep}

Vsak drobec znanja, ki ga učenec pridobi sam - vsak problem, ki ga sam reši - postane mnogo bolj njegov, kot bi bil sicer. Dejavnost uma, ki je spodbudila učenčev uspeh, koncentracija misli, potrebnih zanj in vznemirjenje, ki sledi zmagoslavju, prispevajo $\mathrm{k}$ temu, da se dejstva vtisnejo $\mathrm{v}$ spomin, kot 
se ne bi mogla nobena informacija, ki jo je slišal od učitelja ali prebral v učbeniku, je že mnoga leta nazaj razmišljal Herbert Spencer.

Doživljajska pedagogika je resnična pedagogika. Uporabnost doživljajske pedagogike je v sinergiji pedagogov in uporabnikov v življenjskih situacijah, ki jih združujejo, ki imajo pedagoški potencial in ponujajo dovolj učnih situacij, katerih izkušnje so prenosljive v obči vsakdan.

Nekonvencionalnost zbuja pomisleke, zato si konvencionalni strokovni delavci nikakor ne morejo predstavljati pomena in učno-vzgojnih učinkov nekje daleč od civiliziranega sveta, prepuščeni samim sebi. Doživljajskopedagoški projekti morajo predstavljati izziv izvajalcem in so podvrženi višji stopnji rizika kakor kabinetno-učilniški sistem vzgoje in izobraževanja. Vendar za skupine otrok in mladostnikov, ki imajo v konvencionalnem izobraževalnem sistemu težave, lahko pomeni doživljajska pedagogika pomembno izkušnjo na poti sprejemanja konvencionalnega. Doživljajska pedagogika se spogleduje s socialno deprivilegiranimi skupinami, posebej zato, ker $z$ intenzivnimi programi prinaša pomembne socialne veščine. Iz istega razloga je uporabna za vse skupine otrok in mladostnikov ter druge ciljne skupine.

V Sloveniji smo doživljajsko pedagogiko vzpostavili na raven prepoznavnosti. Posebej na področju socialnopedagoškega dela se je izkazala kot zelo koristna in dobra metoda. Tudi projekti ali pristopi, ki so vezani na bližino izvajanja, z minimalnimi sredstvi, se izkažejo kot učinkoviti. Vsekakor za tem izvajanjem vedno stojijo usposobljeni in visoko motivirani strokovni delavci.

Prav tako se kot obroben del reformne pedagogike kritično reflektira $\mathrm{v}$ odnosu do etabliranega šolstva in izobraževanja nasploh, kakor tudi do vzpostavljenega sistema socialne pomoči in pomoči otrokom in mladostnikom s težavami v svojem socialnem vključevanju.

\section{Literatura}

Breß, H. (1985). Outward Bound - Persönlichkeitsbildung durch Erlebnispädagogik. Die deutschen Kurzschulen als Alternativen zu Passivität und Resignation. Deutsche Jugend, 33(5), 222-226.

Farkaš, M. (2013). Doživljajska pedagogika v osnovni šoli (Diplomsko delo). Univerza v Ljubljani, Pedagoška fakulteta, Ljubljana.

Fischer, T. (1994). Grundbegriffe der Erlebnispädagogik. Erlebnispädagogik, 14(9). 
Fischer, T. (1999). Erlebnispädagogik. Das Erlebnis in der Schule. Frankfurt/M: Peter Lang Verlag.

Fischer, T. (2003). Informelle Pädagogik. Hamburg: Verlag Dr. Kovač.

Fischer, T., in Mroczek, P. M. (2004). Pädagogik und Therapie. Hamburg: Verlag Dr. Kovač.

Freire, P. (1970). Pedagogy of the oppressed. New York, NY: Continuum.

Jeronen, E., Jeronen, J., in Raustia, H. (2009). Environmental Education in Finland - A case study of environmental education in nature schools. International Journal of Environmental \& Science Education, 4(1), 1-23.

Krajnčan, M. (2006). Teoretske osnove doživljajskopedagoškega dela. Doživljajska pedagogika, 12(15), 13-48.

Krajnčan, M. (2007). Osnove doživljajske pedagogike. Ljubljana: Pedagoška fakulteta.

Marttila, M. (2017). Learning in the nature - Integrating outdoor adventure education into the curriculum for adolescents with learning disabilities. Jyväskylä: University of Jyväskylä, Department of Sport Sciences.

Michl, W., in Heckmair, B. (2004). Erleben und Lernen. München: Reinhardt.

Priest, S., in Baillie, R. (1987). Justifying the risk to others: The real razor's edge. Journal of Experiential Education, 16(1), 50-53.

Priest, S., in Gass, M. A. (1997). Effective leadership in adventure programming. New Hampshire: Human Kinetics.

Ziegenspeck, J. (1992). Erlebnispädagogik. Rückblick - Bestandsaufnahme Ausblick. Lüneburg: edition erlebnispädagogik.

Ziegenspeck, J. (1993). Hintergrundinformationen $\mathrm{zu}$ einem praktisch bedeutsamen und theoretisch interessanten Erziehungsfeld. Zeitschrift für Erlebnispädagogik, 13(1), 5-10.

Ziegenspeck, J. (2000). Handbuch Orientierungstuffe. Sachstandsbericht und Zwischenbilanz. Bad Heilbrunn: Klinkhart.

Ziegenspeck, J. (2005). Erlebnispädagogik - eine neue Wissenschaftsdisziplin zwischen Theorie und Praxis, Tradition und Fortschrift, Affirmation und Innovation. V M. Krajnčan in N. Cvirn (ur.), Mesto in vloga doživljajske pedagogike: Zbornik povzetkov 2. slovenskega kongresa doživljajske pedagogike (str. 13-20). Ljubljana: Društvo za doživljajsko pedagogiko Slovenije. 